\title{
Association between Maternal Health Care and Basic Immunization Completeness in Children Aged 12-23 Months: Analysis of 2017 Indonesian Demographic and Health Survey
}

\author{
Indri Faradita ${ }^{1} \mathbb{D}$, Mei Neni Sitaresmi ${ }^{2 *}$ (D) Abdul Wahab $^{3} \mathbb{D}$ \\ ${ }^{1}$ Faculty of Medicine, Public Health and Nursing, Universitas Gadjah Mada, Yogyakarta, Indonesia; ${ }^{2}$ Department of Child \\ Health, Faculty of Medicine, Public Health and Nursing, Universitas Gadjah Mada, DR Sardjito Hospital, Yogyakarta, Indonesia; \\ ${ }^{3}$ Department of Biostatistics, Epidemiology, and Population Health, Faculty of Medicine, Public Health and Nursing, Universitas \\ Gadjah Mada, Yogyakarta, Indonesia
}

Edited by: Ksenija Bogoeva-Kostovska

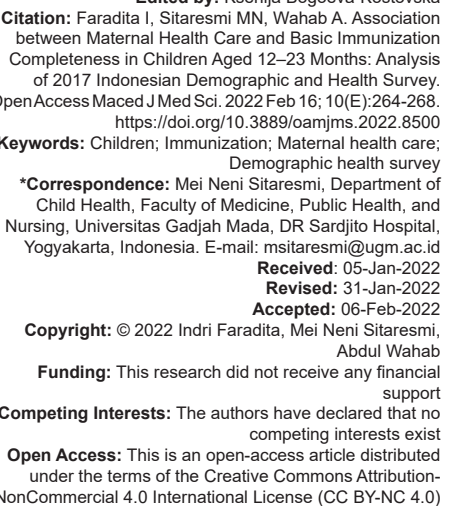
Introduction

Immunization is the most cost-effective health intervention program because it can prevent and reduce morbidity, disability, and mortality due to vaccinepreventable diseases. Recently, vaccination can prevent more than 20 life-threatening diseases. It is estimated that 2- million deaths can be prevented from diseases such as diphtheria, tetanus, pertussis (DTP), influenza, and measles every year [1]. However, despite the success story of vaccination, globally, the immunization coverage for children has decreased from 86\% in 2019 to $83 \%$ in 2020 , increasing 3.4 million children who do not receive immunization. It was estimated that 23 million children under 1 year of age do not receive basic immunization consisting of 17.1 million infants who did not receive the initial dose of the Diphtheria, Pertussis, Tetanus vaccine and 5.6 million children who received only partial vaccination. It indicates a lack of access to immunization and other health services [2].
According to the 2017 health report from the Ministry of Health $(\mathrm{MoH})$, Republic Indonesia, complete basic immunization coverage for children aged 12-23 months has only reached 65\% [3]. This coverage failed to achieve the strategic plan target of $93 \%$, even decreased compared to the 2012 Indonesian Demographic Health Survey (IDHS) results. Children aged 12-23 months who did not receive immunizations even increased from $2013(8.7 \%)$ to (9.2\%) in 2018 [4].

Strategies to increase the provision of complete immunization must be carried out by increasing the continuity of maternal health services since pregnancy, childbirth, and postpartum [5]. Continuity of maternal health services is one of the critical factors for increasing child immunization. Mothers who receive three health services, namely antenatal care (ANC), birth attendants by health workers, and postnatal care (PNC), have a higher probability of providing complete basic immunizations [6].

The coverage of pregnant women in Indonesia who received the minimal 4 times ANC (K4) was 
$77 \%$. Delivery assisted by health workers was $91 \%$, and coverage of PNC visits reached $87 \%$ in 2017 but decreased to $85 \%$ in the following year [3]. There were still significant disparities among provinces and districts regarding maternal health services in the Indonesia [4]. Research correlating the completeness of children's basic immunization with maternal health services focused on three main variables: ANC services, birth attendants, and PNC services in Indonesia, is still limited. The study aims to assess the correlations between maternal health services and complete basic immunization in Indonesian children aged 12-23 months.

\section{Methods}

We conducted a cross-sectional study using data from the 2017 IDHS. This research took place from 24 July to 30 September 2017. The 2017 IDHS successfully interviewed 49,627 eligible women aged 15-49 years. The sample frame of the 2017 IDHS is the Master Sample of Census Blocks from the 2010 Population Census. Two-stage stratified sampling, which covered 1,970 census blocks in urban and rural areas, was used to obtain representative samples from all provinces in Indonesia. In the first stage, several census blocks were selected with systematic sampling proportional to size, where size is the number of households listed in the 2010 Population Census. In the second stage, 25 census blocks representing the number of provinces in Indonesia were selected. Eight families were randomly selected for each selected census block [7].

The outcome of this study was the completeness of children's basic immunizations. Immunization was considered to be complete if the child had received one dose of hepatitis B vaccines, one dose of Bacilli Calmette Guerin (BCG), 3 doses of combination vaccines of DTP, and Hepatitis B, 4 doses of polio, and one dose of measles, according to the immunization national guideline. The sources of information on the immunization status of children were obtained from the vaccination card and report by the mother. The independent variable in this study is maternal health services by focusing on three main variables, namely ANC services, birth attendants, and PNC services. We included children aged 12-23 months, who had complete data on basic immunization completeness, and maternal health services: ANC services, birth attendants, and PNC services, which amounted to 3,398. Furthermore, the results were analyzed using the chi-square test and logistic regression to determine the variables that affect the child immunization completeness. Ethical approval was obtained from the Ethical Committee of Faculty of Medicine, Public Health and Nursing, Universitas Gadjah Mada, no KE/FK/1170/EC/2021.

\section{Results}

Table 1 presents the distribution of the characteristics of respondents. Of the 3,398 samples, $61.4 \%$ had a complete primary immunization. The mean children aged was 17.3 and $50.7 \%$ were male. Most $(91.1 \%)$ mothers had more than four ANC visits, the majority $(92.9 \%)$ of mothers delivered by health workers, and $69.1 \%$ attended PNC. The bivariate analysis in Table 2 presents the significant variables with the completeness of basic immunization: ANC, birth attendants, PNC services, birth order, father's education, mother's education, geographic area, and wealth index. Meanwhile, the mother's occupation, age, and residence were not significantly related to the completeness of immunization.

Table 1: Characteristics of respondents

\begin{tabular}{|c|c|c|}
\hline \multirow[t]{2}{*}{ Variable $(n=3,398)$} & \multicolumn{2}{|l|}{ Total } \\
\hline & $\mathrm{n}$ & $(\%)$ \\
\hline Child aged: mean $( \pm S D)$, years & 17.3 & $(3.42)$ \\
\hline \multicolumn{3}{|l|}{ Immunization status } \\
\hline Completed & 2086 & (61.4) \\
\hline Un-completed & 1312 & (38.6) \\
\hline \multicolumn{3}{|l|}{ Antenatal care (frequency) } \\
\hline$<4$ & 301 & (8.9) \\
\hline $4-8$ & 1310 & (38.5) \\
\hline $8+$ & 1787 & (52.6) \\
\hline \multicolumn{3}{|l|}{ Birth attendant } \\
\hline Non-health professional & 243 & (7.1) \\
\hline Health professional & 3155 & (92.9) \\
\hline \multicolumn{3}{|l|}{ Postnatal care } \\
\hline No received & 1050 & (30.9) \\
\hline Received & 2348 & (69.1) \\
\hline \multicolumn{3}{|l|}{ Birth order } \\
\hline 1 & 1131 & (33.3) \\
\hline $2-3$ & 1835 & $(54.0)$ \\
\hline$\geq 4$ & 432 & (12.7) \\
\hline \multicolumn{3}{|l|}{ Child gender } \\
\hline Male & 1723 & $(50.7)$ \\
\hline Female & 1675 & (49.3) \\
\hline \multicolumn{3}{|l|}{ Father education level } \\
\hline Primary ( $<9$ years) & 978 & $(28.8)$ \\
\hline Secondary (9-12 years) & 1961 & (57.7) \\
\hline Higher (>12 years) & 459 & (13.5) \\
\hline \multicolumn{3}{|l|}{ Mother education } \\
\hline Primary (<9 years) & 832 & $(24.5)$ \\
\hline Secondary (9-12 years) & 2006 & $(59.0)$ \\
\hline Higher (>12 years) & 560 & (16.5) \\
\hline \multicolumn{3}{|l|}{ Mother occupation } \\
\hline Working & 1386 & $(40.8)$ \\
\hline Not working & 2012 & (59.2) \\
\hline \multicolumn{3}{|l|}{ Mother age (years) } \\
\hline$<25$ & 747 & (21.9) \\
\hline $25-34$ & 1749 & (51.5) \\
\hline$\geq 35$ & 902 & (26.6) \\
\hline \multicolumn{3}{|l|}{ Residence } \\
\hline Rural & 1739 & $(51.2)$ \\
\hline Urban & 1659 & (48.8) \\
\hline \multicolumn{3}{|l|}{ Geographic region } \\
\hline Maluku-Papua & 106 & (3.1) \\
\hline Java-Bali & 1947 & (57.3) \\
\hline Sumatera & 746 & $(22.0)$ \\
\hline Kalimantan Sulawesi & 435 & (12.8) \\
\hline NTT-NTB & 164 & (4.8) \\
\hline \multicolumn{3}{|l|}{ Wealth index } \\
\hline Poorest & 675 & (19.9) \\
\hline Poorer & 685 & (20.2) \\
\hline Middle & 654 & (19.2) \\
\hline Richer & 725 & (21.3) \\
\hline Richest & 659 & (19.4) \\
\hline
\end{tabular}

Multivariate analysis using logistic regression found that the correlation between maternal health services and immunization completeness still shows a significant value after controlling for other variables. Mothers who received ANC services more than 8 times during delivery had a 3.52 times greater chance of providing basic immunization to their children than 
Table 2: Association of maternal healthcare and children immunization completeness in Indonesia

\begin{tabular}{|c|c|c|c|c|c|c|c|}
\hline \multirow[t]{3}{*}{ Variable $(n=3,398)$} & \multicolumn{4}{|c|}{ Immunization status } & \multirow[t]{3}{*}{ OR } & \multirow[t]{3}{*}{$(95 \% \mathrm{Cl})$} & \multirow[t]{3}{*}{$p$-value } \\
\hline & \multicolumn{2}{|c|}{ Un-completed $(n=1,312)$} & \multicolumn{2}{|c|}{ Completed $(n=2,086)$} & & & \\
\hline & $\mathrm{n}$ & $(\%)$ & $\mathrm{n}$ & $(\%)$ & & & \\
\hline \multicolumn{8}{|l|}{ Antenatal care (frequency) } \\
\hline$<4$ & 222 & $(16.9)$ & 78 & (3.7) & Ref & Ref & Ref \\
\hline $4-8$ & 499 & $(38.0)$ & 811 & (38.9) & 4.57 & $(3.32-6.29)$ & 0.000 \\
\hline $8+$ & 591 & $(45.1)$ & 1197 & $(57.4)$ & 5.70 & (4.16-7.82) & 0.000 \\
\hline \multicolumn{8}{|l|}{ Birth attendant } \\
\hline Non-health professional & 181 & $(13.8)$ & 62 & (3.0) & Ref & Ref & Ref \\
\hline Health professional & 1131 & $(86.2)$ & 2024 & $(97.0)$ & 5.17 & (3.66-7.29) & 0.000 \\
\hline \multicolumn{8}{|l|}{ Postnatal care } \\
\hline No received & 482 & $(36.7)$ & 568 & $(27.2)$ & Ref & Ref & Ref \\
\hline Received & 830 & (63.3) & 1518 & (72.8) & 1.55 & $(1.29-1.86)$ & 0.000 \\
\hline \multicolumn{8}{|l|}{ Birth order } \\
\hline$\geq 4$ & 219 & $(16.7)$ & 213 & (10.2) & Ref & Ref & Ref \\
\hline 1 & 429 & (32.7) & 702 & (33.7) & 1.64 & $(1.29-2.21)$ & 0.000 \\
\hline $2-3$ & 664 & $(50.6)$ & 1171 & $(56.1)$ & 1.82 & (1.42-2.33) & 0.000 \\
\hline \multicolumn{8}{|l|}{ Child gender } \\
\hline Male & 648 & $(49.4)$ & 1028 & $(49.3)$ & Ref & Ref & Ref \\
\hline Female & 664 & (50.6) & 1058 & (50.7) & 1.00 & $(0.84-1.19)$ & 0.941 \\
\hline \multicolumn{8}{|l|}{ Father education level } \\
\hline Primary (<9 years) & 468 & $(35.7)$ & 511 & (24.5) & Ref & Ref & Ref \\
\hline Secondary (9-12 years) & 701 & $(53.4)$ & 1260 & $(60.4)$ & 1.64 & $(1.35-2.00)$ & 0.000 \\
\hline \multirow{2}{*}{\multicolumn{8}{|c|}{ Mother education level }} \\
\hline & & & & & & & \\
\hline Primary (<9 years) & 416 & $(31.7)$ & 417 & $(20.0)$ & Ref & Ref & Ref \\
\hline Secondary (9-12 years) & 718 & $(54.7)$ & 1288 & (61.7) & 1.79 & $(1.45-2.20)$ & 0.000 \\
\hline Higher ( $>2$ years) & 178 & (13.6) & 381 & (18.3) & 2.12 & $(1.62-2.78)$ & 0.000 \\
\hline \multicolumn{8}{|l|}{ Mother occupation } \\
\hline Working & 535 & $(40.8)$ & 851 & $(40.8)$ & Ref & Ref & Ref \\
\hline Not working & 777 & $(59.2)$ & 1235 & $(59.2)$ & 1.00 & $(0.84-1.19)$ & 0.994 \\
\hline \multicolumn{8}{|l|}{ Mother age (years) } \\
\hline$<25$ & 304 & $(23.2)$ & 443 & $(21.2)$ & Ref & Ref & Ref \\
\hline $25-34$ & 636 & $(48.4)$ & 1114 & $(53.4)$ & 1.19 & $(0.94-1.51)$ & 0.135 \\
\hline$\geq 35$ & 372 & $(28.4)$ & 529 & $(25.4)$ & 0.98 & $(0.75-1.28)$ & 0.890 \\
\hline \multicolumn{8}{|l|}{ Residence } \\
\hline Rural & 706 & $(53.8)$ & 1033 & $(49.5)$ & Ref & Ref & Ref \\
\hline Urban & 606 & $(46.2)$ & 1053 & $(50.5)$ & 1.18 & $(0.91-1.33)$ & 0.053 \\
\hline \multicolumn{8}{|l|}{ Geographic region } \\
\hline Maluku-Papua & 58 & $(4.4)$ & 49 & $(2.4)$ & Ref & Ref & Ref \\
\hline Java-Bali & 692 & (52.7) & 1255 & $(60.1)$ & 3.24 & $(2.16-4.85)$ & 0.000 \\
\hline Sumatera & 361 & $(27.5)$ & 385 & (18.5) & 2.11 & (1.52-2.93) & 0.000 \\
\hline Kalimantan Sulawesi & 158 & (12.1) & 276 & (13.2) & 2.03 & $(1.44-2.86)$ & 0.000 \\
\hline NTT-NTB & 43 & (3.3) & 121 & $(5.8)$ & 1.24 & $(0.89-1.74)$ & 0.198 \\
\hline \multicolumn{8}{|l|}{ Wealth index } \\
\hline Poorest & 336 & $(25.6)$ & 340 & (16.3) & Ref & Ref & Ref \\
\hline Poorer & 284 & (21.6) & 402 & (19.3) & 1.40 & $(1.08-1.82)$ & 0.010 \\
\hline Middle & 235 & (17.9) & 419 & (20.1) & 1.76 & $(1.35-2.29)$ & 0.000 \\
\hline Richer & 244 & (18.6) & 480 & (23.1) & 1.94 & (1.49-2.52) & 0.000 \\
\hline Richest & 213 & $(16.3)$ & 445 & $(21.2)$ & 2.06 & $(1.57-2.71)$ & 0.000 \\
\hline
\end{tabular}

mothers who only visited ANC $<4$. Mothers whose births were assisted by health workers had a 3.32 times chance to provide complete basic immunizations. Mothers who received PNC services after delivery increased the provision of complete basic immunization to children with an Odds ratio (OR) value of 1.31 (1.07-1.59). Children with a birth order of 2-3 have a $1.37(1.04-0.80)$ greater chance of getting immunized than the first child, which is statistically significant. Mothers with higher education levels significantly increased the provision of basic immunization to children with an OR value of 1.64 (1.22-2.20). Respondents living in the Java-Bali area have a 2.61 higher chance of getting complete basic immunization than respondents who live in the Maluku-Papua area (Table 3).

\section{Discussion}

Using the national representative data, we found that the coverage of complete basic immunization among Indonesian children aged 12-23 months in 2017 was $61,4 \%$, still below the target of the Indonesian
Table 3: Analysis multivariate: Association of maternal healthcare and children immunization completeness in Indonesia

\begin{tabular}{|c|c|c|c|}
\hline \multirow{2}{*}{ Variable } & \multicolumn{3}{|c|}{ Immunization Status } \\
\hline & AOR & $95 \% \mathrm{Cl}$ & $\mathrm{p}$-value \\
\hline \multicolumn{4}{|l|}{ Antenatal care (frequency) } \\
\hline$<4$ & Ref & Ref & Ref \\
\hline $4-8$ & 3.23 & $(2.31-4.52)$ & 0.000 \\
\hline$>8$ & 3.52 & $(2.49-4.97)$ & 0.000 \\
\hline \multicolumn{4}{|l|}{ Birth Attendant } \\
\hline Non-health professional & Ref & Ref & Ref \\
\hline Health professional & 3.32 & $(2.26-4.88)$ & 0.000 \\
\hline \multicolumn{4}{|l|}{ Postnatal care } \\
\hline No received & Ref & Ref & Ref \\
\hline Received & 1.31 & $(1.07-1.59)$ & 0.008 \\
\hline \multicolumn{4}{|l|}{ Birth order } \\
\hline$\geq 4$ & Ref & Ref & Ref \\
\hline 1 & 1.11 & $(0.82-1.49)$ & 0.493 \\
\hline $2-3$ & 1.37 & $(1.04-1.80)$ & 0.024 \\
\hline \multicolumn{4}{|l|}{ Mother education* } \\
\hline Primary (<9 years) & Ref & Ref & Ref \\
\hline Secondary (9-12 years) & 1.50 & $(1.19-1.88)$ & 0.000 \\
\hline Higher ( $>12$ years) & 1.64 & $(1.22-2.20)$ & 0.001 \\
\hline \multicolumn{4}{|l|}{ Geographic region } \\
\hline Maluku-Papua & Ref & Ref & Ref \\
\hline Java-Bali & 2.61 & $(1.72-3.97)$ & 0.000 \\
\hline Sumatera & 1.23 & $(0.87-1.73)$ & 0.224 \\
\hline Kalimantan-Sulawesi & 1.42 & $(1.00-2.02)$ & 0.049 \\
\hline NTT-NTB & 0.84 & $(0.59-1.18)$ & 0.325 \\
\hline
\end{tabular}

$\mathrm{MoH}$ strategic planning of $90 \%$ coverage [8]. This 2017 child immunization coverage is almost the same as the 2013 coverage reported by Holipah et al. (2018), which used the 2013 Indonesian National Socioeconomic [9]. 
Identifying how maternal health services and other determinants of children immunization is essential to improve the coverage of children's immunization in Indonesia.

This research found a relationship between maternal health services and the children's basic immunization completeness. In line with the study conducted in 29 countries in sub-Saharan Africa, mothers who use maternal health services (ANC visits, delivery by health workers, and PNC visits) have a higher chance of providing complete immunization to their children. Frequent contact with health services provides an opportunity for mothers to obtain accurate information about health care and makes mothers aware of the importance of immunization for their children [10].

In line with research conducted by India, we also found that mothers whose births were assisted by health professionals were proven to increase the provision of complete immunization significantly [11]. Based on the expended program immunization recommendations, health workers must provide hepatitis $B$ immunization to all newborns within $24 \mathrm{~h}$ of birth. Therefore, newborns can receive immunizations immediately after birth if health workers carry out birth attendants, and mothers can obtain adequate information from health workers about the correct immunization sequence [9].

This study showed that mothers who received $\mathrm{PNC}$ services after delivery had a 1.31 times greater chance of giving complete immunizations to their children. This finding confirmed the result of a previous study in 12 East Africa countries that also used demographics and health that found mothers who had PNC visits had a 1.34 times higher chance of fully vaccinating their children than mothers who did not have PNC visits [12]. PNC visits provide an opportunity for health workers to administer BCG, and polio vaccinations thereby increasing adherence to the immunization program and creating opportunities to start vaccinating children who are not immunized [13].

Similar to a study conducted in urban slums of Western Maharashtra, India, we found that higher education level was found to have a significant relationship with the complete basic provision for children with an OR value of 1.64 [14]. This may be because mothers with higher education have better knowledge, awareness, health-seeking behavior, and decisionmaking capacity than mothers with lower education. Education can provide a greater understanding of health services and the ability to respond to new knowledge more quickly. Educated mothers may be more aware of the importance of immunization and choose health care services that result in better health status for their children [15]. Nescience and lack of awareness of parents about immunization make children miss the proper immunizations, which in turn increases the likelihood of malnutrition, child mortality, and morbidity [16].
Reviewed from the aspect of the geographical area, it was found that children living in the Java-Bali region had a 2.61 higher chance of getting complete basic immunization than children living in the Maluku and Papua regions. This can be explained by the fact that the geographical differences in each region in Indonesia will affect the level of basic immunization. Remote areas will find it difficult to access the health [17]. Regional differences are associated with a lack of strengthening of the health care system that contributes to immunization failures caused by differences in vaccine supply, availability of health care providers, poorly regulated immunization services or appointments, lack of tracking systems for child absenteeism, poor counseling services. And access to the health facilities [15].

Using a cross-sectional study is the limitation of the study. Therefore, the results only support an association between determinant variables and child immunization completeness, not causality. Another limitation is the study used the 2017 IDHS. Our study aimed to assess the correlations between maternal health services and complete basic immunization in Indonesian children aged 12-23 months. The latest National data that provides individual data both on maternal care (ANC, birth attendants by health workers, and PNC) and child immunization is the 2017 IDHS. IDHS is conducted every 5 years, and the result of the 2021 IDHS has not been published. Indonesian $\mathrm{MoH}$ annually reports the health data, but it is aggregate data, not individual data. For the comparison, based on the 2020 Indonesian $\mathrm{MoH}$ annually reports, there is a slightly increased coverage of the ANC (1.2\%), birth attendance by health care providers (5.0\%), and PNC (2.5\%) as well as child immunization (2.5\%) from 2017 to 2019 (before the COVID-19 Pandemic). In 2020, due to COVID-19 Pandemic, the coverage decreases $2.7 \%$ (ANC), 10.6\% (PNC), and 8.5\% (child immunization) [18]. Another data from the Indonesian Statistic Agency also reported a similar finding, a slightly comparable increase of birth attendance by health providers (1.46\%) [19] and complete child immunization (5.1\%) [20]. From those data, we can assume that our study still represents the recent Indonesian condition. However, despite this limitation, using a nationally representative sample from a population-based survey that covers every district in Indonesia is the strength of this study.

\section{Conclusion and Recommendation}

Maternal health services, which consist of ANC services during pregnancy, delivery by health workers, and PNC services, were associated with the completeness of basic immunization in children 
aged 12-23 months in Indonesia. The utilization of maternal health services since pregnancy, childbirth, and postpartum is essential to increase complete basic immunization coverage. It is necessary to provide counseling to increase knowledge, attitudes, and behavior of pregnant women on the importance of utilizing sustainable maternal health services.

\section{References}

1. WHO. Vaccines and Immunization. Geneva: World Health Organization; 2018. Available from: https://www.who.int/healthtopics/vaccines-and-immunization\#tab=tab 1 [Last accessed 2021 Dec 24].

2. WHO. Immunization Coverage. Geneva: World Health Organization; 2020. Available from: https://www.who.int/newsroom/fact-sheets/detail/immunization-coverage [Last accessed 2021 Dec 28].

3. Indonesian Ministry of Health. The 2017 Indonesian Health Profile [Profil Kesehatan Indonesia 2017]. Jakarta: Indonesian Ministry of Health; 2018. Available from: https://www.kesmas. kemkes.go.id/assets/upload/dir_519d41d8cd98f00/files/Hasilriskesdas-2018_1274.pdf [Last accessed 2021 Dec 28].

4. Indonesian Ministry of Health. The Main Result of Basic Health Research 2018 [Hasil Utama RISKESDAS 2018]. Jakarta, Indonesia: Indonesian Ministry of Health; 2018. Available from: http://www.depkes.go.id/resources/download/info-terkini/ materi rakorpop_2018/hasil riskesdas 2018.pdf [Last accessed 2021 Dec 19].

5. Putri DS, Utami NH, Nainggolan O. Association between the sustainability utilization of maternal health care and immunization completeness in Indonesia. Indones J Reprod Health. 2016;7(2):135-44. https://doi.org/10.22435/kespro. v7i2.4966.135-144

6. Usman M, Anand E, Siddiqui L, Unisa S. Continuum of maternal health care services and its impact on child immunization in India: An application of the propensity score matching approach. J Biosoc Sci. 2021;53(5):643-62. https://doi.org/10.1017/ S0021932020000450

PMid:32830633

7. National Population and Family Planning Board (BKKBN), Statistics (BPS), Ministry of Health (Kemenkes), ICF. Indonesia Demographic and Health Survey 2017. Jakarta, Indonesia: BKKBN, BPS, Kemenkes, and ICF; 2018. Available from: https://www.dhsprogram.com/pubs/pdf/FR342/FR342.pdf [Last accessed 2021 Dec 30].

8. Indonesian Ministry of Health. The Main Points of the Minitry of Health Strategic Plan 2020-2024 [Pokok-Pokok Renstra Kemenkes 2020-2024]. Indonesia: Indonesian Ministry of Health; 2020. Available from: https://www.e-renggar.kemkes. go.id/file2018/e-performance/1-119014-2tahunan-870.pdf [Last accessed 2021 Dec 26].

9. Holipah, Maharani A, Kuroda Y. Determinants of immunization status among 12-to 23-month-old children in Indonesia (2008-2013): A multilevel analysis. BMC Public Health.
2018;18(1):288. https://doi.org/10.1186/s12889-018-5193-3 PMid:29482562

10. Budu E, Ahinkorah BO, Aboagye RG, Armah-Ansah EK, Seidu AA, Adu $C$, et al. Maternal healthcare utilsation and complete childhood vaccination in sub-Saharan Africa: A cross-sectional study of 29 nationally representative surveys. BMJ Open. 2021;11(5):e045992. https://doi.org/10.1136/bmjopen-2020-045992 PMid:33986059

11. Kumar V. Determinants of immunization coverage and associated factors among children aged under two-year-old in the national immunization program of Mewat district, Haryana (2019-2020). Texila Int J Public Health. 2021;9(1):176-96. https://doi.org/10.21522/tijph.2013.09.01.art019

12. Tesema GA, Tessema ZT, Tamirat KS, Teshale AB. Complete basic childhood vaccination and associated factors among children aged 12-23 months in East Africa: A multilevel analysis of recent demographic and health surveys. BMC Public Health. 2020;20(1):1837. https://doi.org/10.1186/s12889-020-09965-y PMid:33256701

13. Acharya P, Kismul H, Mapatano MA, Hatløy A. Individual-and community-level determinants of child immunization in the Democratic Republic of Congo: A multilevel analysis. PLoS One. 2018;13(8):e0202742. https://doi.org/10.1371/journal. pone. 0202742

PMid:30138459

14. Mitkari KK, Haralkar S. A cross-sectional study of immunization coverage in children in urban slums of Western Maharashtra. Asian Pac J Health Sci. 2020;7(2):22-5. https://doi.org/10.21276/ apjhs.2020.7.2.5

15. Awol M, Alemu ZA, Moges NA, Jemal K. Geographical variations and associated factors of defaulting from immunization among children aged 12 to 23 months in Ethiopia: Using spatial and multilevel analysis of 2016 Ethiopian demographic and health survey. Environ Health Prev Med. 2021;26(1):65. https://doi. org/10.1186/s12199-021-00984-8

PMid:34118886

16. Panda BK, Kumar G, Mishra S. Understanding the fullimmunization gap in districts of India: A geospatial approach. Clin Epidemiol Glob Health. 2020;8(2):536-43. https://doi. org/10.1016/j.cegh.2019.11.010

17. Aalemi AK, Shahpar K, Mubarak MY. Factors influencing vaccination coverage among children age 12-23 months in Afghanistan: Analysis of the 2015 demographic and health survey. PLoS One. 2020;15(8):e0236955. https://doi. org/10.1371/journal. pone. 0236955

PMid:32764770

18. Indonesian Ministry of Health. The 2020 Indonesian Health Profile [Profil Kesehatan Indonesia 2020]. Indonesia: Indonesian Ministry of Health; 2020. Available from: https://www.pusdatin. kemkes.go.id/folder/view/01/structure-publikasi-pusdatin-profilkesehatan.html [Last accessed 2022 Jan 19].

19. Indonesian Statistic Agency. Percentage of Birth Attended by Health Worker. Indonesia: Indonesian Statistic Agency; 2020. Available from: https://www.bps.go.id/indikator/indikator/view_ data/0000/data/1345/sdgs_3/1 [Last accessed 2022 Jan 02].

20. Indonesian Statistic Agency. Complete Child Immunization. Indonesia: Indonesian Statistic Agency; 2020. Available from: https://www.bps.go.id/indikator/indikator/view data/0000/ data/1545/sdgs_1/1I [Last accessed 2022 Jan 02]. 